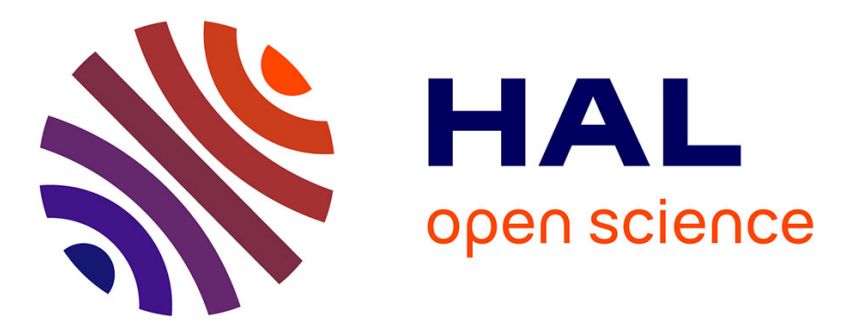

\title{
Painful semantic context modulates the relationship between action words and biological movement perception
}

Christel Bidet-Ildei, Manuel Gimenes, Lucette Toussaint, Sophie-Anne Beauprez, Arnaud Badets

\section{To cite this version:}

Christel Bidet-Ildei, Manuel Gimenes, Lucette Toussaint, Sophie-Anne Beauprez, Arnaud Badets. Painful semantic context modulates the relationship between action words and biological movement perception. Journal of Cognitive Psychology, 2017, 29 (7), pp.821 - 831. 10.1080/20445911.2017.1322093 . hal-01722552

\section{HAL Id: hal-01722552 \\ https://hal.science/hal-01722552}

Submitted on 18 Jan 2019

HAL is a multi-disciplinary open access archive for the deposit and dissemination of scientific research documents, whether they are published or not. The documents may come from teaching and research institutions in France or abroad, or from public or private research centers.
L'archive ouverte pluridisciplinaire HAL, est destinée au dépôt et à la diffusion de documents scientifiques de niveau recherche, publiés ou non, émanant des établissements d'enseignement et de recherche français ou étrangers, des laboratoires publics ou privés. 
Painful semantic context modulates the relationship between action words and biological movement perception

Bidet-Ildei Christel*, Gimenes Manuel*, Toussaint Lucette*, Sophie-Anne Beauprez* \& Badets Arnaud*+

*Université de Poitiers; Université François Rabelais de Tours; Centre National de la Recherche Scientifique, Centre de Recherches sur la Cognition et l'apprentissage (UMR 7295), Poitiers, France

+ Centre National de la Recherche Scientifique; Université de Bordeaux, Institut de Neurosciences Cognitives et Intégratives d'Aquitaine (UMR 5287), Bordeaux, France

Corresponding author: Christel Bidet-Ildei

Mailing Address:

Christel Bidet-Ildei (PhD)

CeRCA/MSHS, Bâtiment A5

5, rue Théodore Lefebvre

TSA 21103

86073 Poitiers cedex 9

Tel.: 33 (0)5 49454697

Fax: 33 (0)5 49454616

Email: christel.bidet@univ-poitiers.fr 


\begin{abstract}
Studies have revealed a close relationship between action-word processing and the detection of point-light biological movements and that this effect can be modulated by the context of action-verb presentation. The goal of the present study was to further examine the extent to which motor representation activation plays a role in this relationship by testing the influence of painless/painful sentence understanding during a listening task. Participants judged the presence or absence of a point-light biological movement that was embedded in a scrambled mask after a congruent or incongruent action sentence was presented. The sentences varied according to the context of action-verb presentation (painful, painless). Perceptual judgments of human movements improved after a prior presentation of a congruent action sentence but only in the painless context. Thus, our findings show that pain included in a semantic context of sentence presentation can preclude the relationship between action-word understanding and point-light biological movement judgments.
\end{abstract}

Key words: biological motion, action sentence, linguistic context, perceived pain. 


\section{Introduction}

In the past forty years, it has been well established that humans are very sensitive to biological motion (BM) produced by living organisms. Observers need only about $100 \mathrm{~ms}$ to recognize daily-life actions presented as "point-light displays", which represent the movement of an actor's various limbs (Johansson, 1973). Moreover, when processing point-light BM, observers are able to access an actor's characteristics, such as gender (Kozlowski \& Cutting, 1977; Troje, Sadr, Geyer, \& Nakayama, 2006), identity (Beardsworth \& Buckner, 1981; Loula, Prasad, Harber, \& Shiffrar, 2005), emotions (Atkinson, Dittrich, Gemmell, \& Young, 2004; Chouchourelou, Matsuka, Harber, \& Shiffrar, 2006) and intentions (Iacoboni et al., 2005; Martel, Bidet-Ildei, \& Coello, 2011). In relation to embodied cognition theory, which postulates that language, abstract and symbol processing emerge from sensorimotor experience (Barsalou, 1999; Wilson, 2002), some studies have shown that BM perception is also related to higher-level cognitive processes, such as action-word processing (Bidet-Ildei, Sparrow, \& Coello, 2011; Bidet-Ildei \& Toussaint, 2015; Springer, Huttenlocher, \& Prinz, 2012; Springer \& Prinz, 2010; Troyer, Curley, Miller, Saygin, \& Bergen, 2014). For example, Bidet-Ildei et al. (2011) show that reading an action verb facilitates the subsequent detection of congruent point-light action embedded in a high-density dynamical point light.

Altogether, these studies are consistent with previous literature that has shown an overlap between action verbs and BM perception in the brain (Khader, Jost, Mertens, Bien, \& Rosler, 2010; Tettamanti et al., 2005). Moreover, they accord with the idea that action and language are based on the activation of similar action representations (Andres, Finocchiaro, Buiatti, \& Piazza, 2015; Aravena et al., 2014; Bidet-Ildei et al., 2011; Bidet-Ildei \& Toussaint, 2015; Heard, Masson, \& Bub, 2015).

More recently, some studies have shown that the context of action-word presentation can influence the relationship between language and action (Aravena et al., 2014; Aravena et al., 
2012; Gilead, Liberman, \& Maril, 2013; Taylor \& Zwaan, 2008; Troyer et al., 2014; van Dam, Brazil, Bekkering, \& Rueschemeyer, 2014; van Dam, van Dijk, Bekkering, \& Rueschemeyer, 2012; Zwaan, Taylor, \& de Boer, 2010). For example, it has been shown that motor activation during action-verb processing appears only when action verbs are presented in affirmative sentences (Aravena et al., 2012). In the same manner, the plausibility of sentence context can affect the relationship between action verbs and BM perception, as illustrated by the increase in visual detection capacity when a congruent action verb is embedded in a plausible sentence (e.g., the neighbor is running in the garden) in comparison with when the same action verb is embedded in an implausible sentence (e.g., the garden is running in the neighbor; Bidet-Ildei, Gimenes, Toussaint, Almecija, \& Badets, In press). However, many questions remain about the impact of semantic context on the relationship between action verbs and BM perception, and the aim of the present experiment was to fill this gap. More specifically, it remains unclear whether the plausibility context effect (BidetIldei et al., In press) is due to the linguistic incoherence of implausible sentences (i.e., inanimate objects were the subjects of action) or to the impossibility of activating motor representations in these sentences. The present experiment aimed to rule out the second hypothesis by contrasting semantically plausible sentences that incite more or less motor representation. To do so, sentences that implied and did not imply pain were compared.

Until now, the effects of pain have been investigated by studying the behavior of subjects who were exposed to pictures representing painful situations (Anelli, Borghi, \& Nicoletti, 2012; Avenanti, Bueti, Galati, \& Aglioti, 2005; Avenanti, Minio-Paluello, Bufalari, \& Aglioti, 2006; Morrison, Poliakoff, Gordon, \& Downing, 2007; Morrison, Tipper, Fenton-Adams, \& Bach, 2013). For example, Avenanti et al. (2005) showed that the motor evoked response decreased when humans watched a needle inserted deep into a hand, suggesting that humans are sensitive to pain inflicted on others. This effect is related to the fact that experiencing pain 
oneself and perceiving pain in others lead to similar patterns of activation (see Lamm, Decety, \& Singer, 2011 for review). Interestingly, it has recently been shown that pain can also affect humans' behavior when it is not directly perceived but only suggested by a situation. In this view, Anelli et al. (2012) showed that when humans perform an object categorization task after the presentation of a grasping hand, they are affected by the evoked aversive affordance of the object. For example, judgement response times are longer when an object is associated with a painful grasp (e.g., a cactus), whereas facilitation is observed when an object is not associated with a painful grasp (e.g., tomato). Finally, a previous study found that body pain can affect our capacity to use our motor system (Mercier, 2012). Specifically, mental rotation tasks, based on the capacity to use motor representations (e.g., Toussaint \& Meugnot, 2013), have been found to be less efficient among participants suffering from pain than among healthy controls (Coslett, Medina, Kliot, \& Burkey, 2010a, 2010b). Therefore, previous investigations have clearly shown that perceived pain influences motor behavior and the capacity to activate motor representations. Here, we wanted to investigate the impact of pain when it is only suggested in a semantic context of oral sentence presentation. Previous studies have shown that pain can be represented by images and/or lexicalizations (Prieto Velasco \& Tercedor Sanchez, 2014). Therefore, without any physical manipulation, we speculated that a verbal description of a painful situation would be sufficient to evoke pain in our participants. Specifically, our objective was to determine how pain suggested with lexicalization can impact the relationship between action-word processing and BM perception. To do so, we examined how visual judgments of point-light human actions vary with the pain that is associated with action verbs. Based on the literature that suggests that the language-action link is related to the degree of effort required to execute an action (Moody \& Gennari, 2010), we hypothesized that painful sentences would preclude the detection of BM. More specifically, we expected that the facilitation of point-light detection usually obtained when 
point-light sequences are primed by congruent action words would decrease when action verbs were presented in a painful context.

\section{Method}

\section{Participants}

Twenty-two students (10 women, 12 men; mean age $=20.2$ years; $\mathrm{SD}=1.2$ years) at the University of Poitiers participated in the study. In a survey, each participant indicated that he/she was healthy, had normal or corrected-to-normal vision and had no history of motor or neurological disorders. Before testing, they were naïve to the aims of the experiment. All participants gave their informed consent prior to their inclusion in the study and received course credits for their participation.

\section{Materials and procedure}

The stimuli consisted of four avi-format animations showing point-light sequences that represented either biological motions or scrambled motions embedded in mask composed of moving scrambled dots. Biological movements represented the side view of a man facing left while walking (without translation) or sitting on a virtual chair. The animations were composed of 13 points of light located on the main body joints (shoulders, elbows, wrists, hips, knees and ankles) and the head. However, 10 to 13 dots were simultaneously visible during the duration of the animation due to transiently hidden points. On average, we considered that each stimulus therefore constituted eleven dots. They were presented at the center of a screen and sustained a $4.5^{\circ}$ (Horizontal, H) $* 11^{\circ}$ (Vertical, V) visual angle. Scrambled movements consisted of eleven dots positioned at a random location in the same spatial window of biological movements. The dynamics of scrambled movements were based on each biological equivalent to obtain a scrambled walking and a scrambled sitting movement. The animation sequences (biological or scrambled) were composed of 55 frames 
that corresponded to the time necessary to obtain one complete cycle of the sitting action. Each frame lasted $25 \mathrm{~ms}$, which resulted in a total duration of $1375 \mathrm{~ms}$. The generation of the stimuli was controlled by Matlab software using the coordinates provided by a point-light action corpus that was accessible on the following website: http://astro.temple.edu/ tshipley/mocap/dotMovie.html (see Shipley \& Brumberg, 2004 for further details about the stimuli). Each point-light display consisted of white dots $(97 \mathrm{~cd} / \mathrm{m} 2$, $\varnothing: 0.65^{\circ}$ of visual angle) presented on a dark background $(0.14 \mathrm{~cd} / \mathrm{m} 2)$. Using the avi file Matlab routine (http://www.mathworks.com/), each sequence was transformed into an avi movie $(640 * 512$ pixels with a frame rate of 40 frames/s). The mask was composed of 55 scrambled dots, in accordance with a previous experiment that showed that 55 moving scrambled dots sufficiently masks point-light human movements while allowing for detection (Bidet-Ildei, Chauvin, \& Coello, 2010). Each dot in the mask appeared randomly on the screen and was animated with an angular motion and amplitude depending on the individual velocity vector of the point-light display. Velocity vectors were sampled from one of the eleven points of the target stimuli (walking or sitting) ( $\mathrm{x}$ and $\mathrm{y}$ coordinates were processed independently). Consequently, two animation sequences in a human action (11 moving dots) embedded in 55 scrambled moving dots (walking and sitting) and two animation sequences composed of 66 scrambled moving dots (scrambled walking, and scrambled sitting) were built. Biological and scrambled point-light stimuli sustained a $21.7^{\circ}(\mathrm{H}) * 19^{\circ}(\mathrm{V})$ visual angle.

Before the stimuli presentation, participants listened to a sentence describing an action using closed supra-aural headphones (Sennheiser HD 202). All sentences had been previously recorded in French with a tape microphone (MARANTZ professional PMD 660) associated with a cardioid microphone (Sennheiser MK4). Sentence segmentation was performed with Audacity software (http://audacity.sourceforge.net/). 
Importantly, the sentences were linguistically coherent but differed in terms of the pain associated with the action context. Therefore, we compared painless (e.g., "the neighbor is walking on a patio" / "the tourist is sitting on a rock") and painful (e.g., "the neighbor is walking $^{1}$ on a viper" / "the tourist is sitting on a scorpion") context. All complements were matched in terms of frequency (mean painless sentences $=13.03$, mean painful sentences $=$ $6.99 ; \mathrm{t}_{38}=-1.71 ; \mathrm{p}=0.09$ ), number of letters (mean painless sentences $=6.25$, mean painful sentences $\left.=6.50 ; \mathrm{t}_{38}=0.59 ; \mathrm{p}=0.55\right)$ and number of syllables (mean painless sentences $=$ 1.70 , mean painful sentences $\left.=1.85 ; \mathrm{t}_{38}=0.76 ; \mathrm{p}=0.45\right)$ with the Lexique 3 database $(\mathrm{New}$, Pallier, Ferrand, \& Matos, 2001). All characteristics of the words used as complements in both conditions are presented in Appendix 1.

Painless and painful sentences contained action words that were related to point-light stimuli according to a congruent or incongruent semantic relationship. For example, a point-light walking movement could be presented after a sentence containing the verb "walk" or the verb "sit".

\section{Apparatus}

Participants sat comfortably in a dimly lit room facing a 16" CRT computer screen (Nokia 4472a, spatial resolution: $1280 * 800$ pixels, sampling rate: $60 \mathrm{~Hz}$ ) that was placed on a horizontal table at a viewing distance of $50 \mathrm{~cm}$. The visual angle of the screen subtended at eye level was $26^{\circ}$ vertical $* 32^{\circ}$ horizontal. Responses were given with a SRbox that was positioned on the table close to the body so that participants could easily provide their response during the experiment by pressing one of the keyboard keys.

\footnotetext{
${ }^{1} \mathrm{We}$ are conscious that "walking on a viper" is not really appropriate here because the animal is simply too small to walk on; it would be better to say one "stepped". However, in French, the verb "marcher" refers to both stepping on (short action with clear beginning and end points; you put your foot on viper) and walking on (continuous action where you plant multiple steps on a viper). Therefore, to support the idea that it was always the same "verb" used in the different conditions, we prefer to use "walk" throughout the manuscript.
} 


\section{Procedure}

Before starting the experiment, participants were familiarized with point-light sequences of biological and non-biological movement presented alone and embedded in a mask. In this familiarization, we used running and throwing stimuli. The stimuli used for this familiarization were not used in the main experiment.

In the experimental session, the participants had to judge the presence or absence of a pointlight human action in a whole image of moving dots (detection task) as quickly and accurately as possible. The visual stimulus contained either a human action (walking, sitting) or only scrambled moving dots (scrambled walking or scrambled sitting) embedded in a dynamic mask of 55 dots. Before the stimuli presentation, participants listened to a sentence that contained a verb presented in a painless or painful context (see materials). No specific task was imposed on the participants during the sentence listening, but the instructions emphasized that they should listen to the sentences with great attention.

The stimuli presentation and manual response registration were controlled by E-prime software (version 2.0, http://www.pstnet.com/). The responses (Yes, No) were recorded by pressing the left button ("no" response) or right button ("yes" response) of an SRbox with the left and the right hand, respectively.

Each stimulus (biological or scrambled motion) was associated with the various sentences in two equivalent random blocks, resulting in a session of 320 trials (40 sentences $* 4$ stimuli $* 2$ blocks) with a total duration of approximately $25 \mathrm{~min}$. A break was provided to the participants between the two blocks. At the end of the experiment, a short questionnaire about the sentences was given to the participants (see appendix 3).

\section{Data analysis}


The analyses assessed hits (i.e., responding "Yes" when the stimulus is present), omissions (i.e., responding "No" when the stimulus is present), correct rejections (i.e., responding "No" when the stimulus is absent) and false alarms (i.e., responding "Yes" when the stimulus is absent) for each subject. Next, $d$ ' and $c$ values, which are standard measures of sensitivity and strategy in signal detection theory (Macmillan \& Creelman, 2005), were calculated according to the sentence type (painless, painful) and congruency (congruent, incongruent). The $d$ ' value represents participants' sensitivity to the stimulus. It is measured by the distance between the signal and noise distribution (i.e., the probability of hits minus the probability of false alarms). When $d^{\prime}$ is high, there is a greater capacity to detect the stimulus. When $d^{\prime}$ 'is equal to 0 , detection is random. The $c$ value reveals the participant's strategy. It represents the distance from the actual threshold for an ideal observer, which conjointly minimizes the probability of a miss and a false alarm. When the $c$ value is negative, the participant is liberal (i.e., responds "yes" more often than the ideal observer), but when $c$ is positive, the participant is conservative (i.e., responds "no" more often than the ideal observer).

Moreover, we computed the mean response time for hits (i.e., the amount of time required to provide a good response from the onset of the stimulus presentation) according to the different priming conditions. In this analysis, we removed data with more than 2.5 standard deviations $(2.65 \%$ of the data).

Variations in each variable were assessed according to the sentence type (painless, painful) and congruency (congruent, incongruent). The statistical analyses were two-way analyses of variance $(\mathrm{ANOVA})^{2}$, and both variables were considered within-subject factors. Duncan's Multiple Range test was used for post-hoc comparisons.

\section{Results}

\footnotetext{
${ }^{2}$ Analyses were performed with RT and log RT, and effects were identical. Here, the results for RT are reported.
} 


\section{Analysis of d' and c}

The $d$ ' value analysis (see Figure 1A) revealed no significant effect of sentence type $(\mathrm{F}(1,21)$ $=1.63, M S E=0.23)$ or congruency $(\mathrm{F}(1,21)=0.62, M S E=0.23)$. There was no interaction between these factors $(F(1,21)=0.20, M S E=0.49)$. This result indicated that sensitivity to the biological movements did not vary by priming condition (mean=1.12 \pm 0.57 ).

For the $c$ values, there was no effect of sentence type $(\mathrm{F}(1,21)=1.44, M S E=0.05)$ or congruency $(\mathrm{F}(1,21)=2,32, M S E=0.20)$. There was no interaction between these factors $(\mathrm{F}(1,21)=0.27, M S E=0.12)$, which indicated that participants used similar response strategies, regardless of the semantic context. The mean $(0.79 \pm 0.23)$ indicated that all of the participants adopted a "conservative" strategy and tended to answer that they did not detect a biological movement in the display.

Table 1: Mean and standard deviation of d' and $\mathrm{c}$ in the different conditions.

\begin{tabular}{|llcc|}
\hline \multirow{2}{*}{ Painless conditions } & Congruent & d' & c \\
& & $0.98 \pm 0.73$ & $0.65 \pm 0.35$ \\
\cline { 2 - 4 } & Incongruent & $1.13 \pm 0.79$ & $0.80 \pm 0.40$ \\
\hline Painful conditions & Congruent & $1.18 \pm 0.70$ & $0.71 \pm 0.33$ \\
\cline { 2 - 4 } & Incongruent & $1.12 \pm 0.57$ & $0.79 \pm 0.23$ \\
\hline
\end{tabular}

\section{Response time}

The ANOVA that was performed on response times (see Figure 1) revealed no significant effect of sentence type $(\mathrm{F}(1,21)=2.26, M S E=1903)$ or congruency $(\mathrm{F}(1,21)=0.41, M S E=$ 2438). Importantly, there was a significant interaction between congruency and sentence type $(\mathrm{F}(1,21)=12.25, M S E=691, \mathrm{p}<.01)$. Post-hoc analyses revealed that point-light movements were more quickly detected in congruent sentences than in incongruent sentences. However, this effect appeared only for painless sentences $(\mathrm{p}<.01)$ and not for painful sentences $(\mathrm{p}=$ 
0.14). Interestingly, the "painless congruent" condition significantly differed from all other conditions $(\mathrm{p}<.05$ for each comparison), while there was no significant difference between them ( $p>.14$ for each comparison).

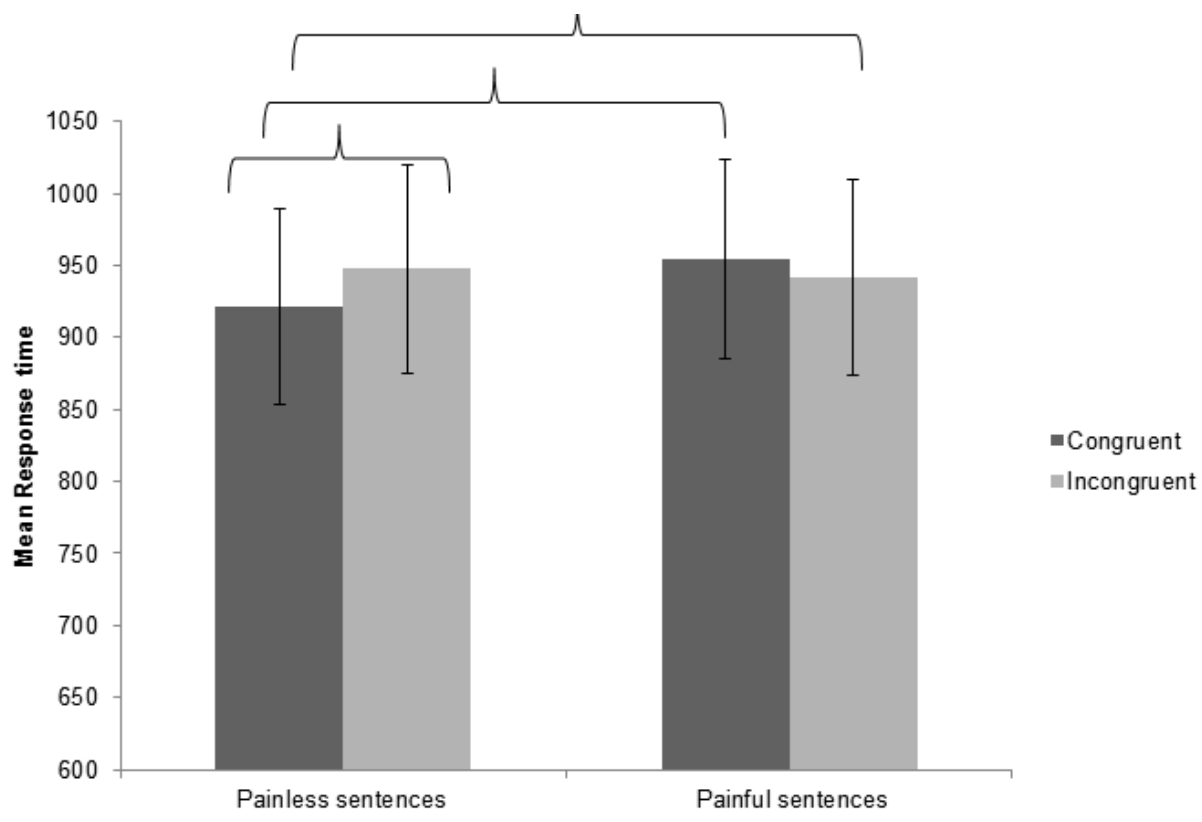

Figure 1: Mean response times according to the sentence type and the congruency. An asterisk indicates significant difference at $\mathrm{p}<0.05$. Error bars represent one standard error of the mean.

\section{Discussion}

The current experiment explored whether a semantic context implying painful/painless information can modulate the relationship between action-verb comprehension and point-light human movement detection. For painless sentences, our results confirmed the facilitation effect usually observed in the detection of BM when they are primed by congruent action verbs (Bidet-Ildei et al. 2011). Moreover, the results demonstrated that this effect is precluded when an action verb is presented in a painful semantic context. Altogether, these findings accord with previous results that have shown that semantic context affects the relationship between action words and the motor system (Aravena et al., 2014; Aravena et al., 2012; 
Bidet-Ildei et al., In press; Gilead et al., 2013; Taylor \& Zwaan, 2008; Troyer et al., 2014; van Dam et al., 2014; van Dam et al., 2012; Zwaan et al., 2010). Moreover, they demonstrate that pain suggested in the sentences directly precludes the relationship between action verbs and BM detection. Remarkably, this effect appears only in the response time analysis and does not affect detection capacity. However, given that analysis of $d$ ' does not reveal an effect of congruency and that $d^{\prime}$ is high in all conditions (mean=1.38), we can hypothesize that the $\mathrm{BM}$ detection task used in the present work is too easy to emphasize significant effects in detection. Future experiments should be carried out with more difficult tasks to assess whether painful semantic context can affect BM detection capacity.

Concerning the lack of facilitation in detecting point-light human movements when congruent action words are presented in a painful context, several theoretical accounts can be envisaged. First, from a linguistic perspective, we can hypothesize that painful sentences are less probable and familiar than painless sentences, which may modify its relationship with human movement detection. In this context, we can hypothesize that priming congruent action words may occur only when the sentence-processing load is low (i.e., due to a high typicality of the sentence) but could be impaired when the sentence-processing load is high. As such, unfamiliar linguistic material is more attention-grabbing than familiar (e.g., Bicknell, Elman, Hare, McRae, \& Kutas, 2010), and it is probable that it is more costly to understand painful sentences. Thus, we should predict that processing painful sentences will hinder point-light display detection independent of action-word congruency. However, our results provided only partial support for this hypothesis because there was no significant effect of sentence type on sensitivity (i.e., $d$ ' analysis) or response times. Therefore, from a linguistic point of view, the present study found that painful sentences are not more difficult to treat than painless sentences. 
One alternative explanation is that the congruency between an action word and an observed action is not equivalent when action words are included in painless or painful contexts. This leads to poor congruence between perceived and imagined action and hence a weaker or absent congruency effect. Point-light human stimuli represent the "normal production" of each action, and actions may not be produced in the same way in a painful context. For example, if we step on a painful object, our next steps could be smaller and more hesitant. However, if this explanation is credible for the "walking condition", it is less so for the "sitting condition" because the point-light sitting action is stopped as soon as the actor is seated. Indeed, in our sentences, the pain appeared only when the action was finished (i.e., the first part of sitting was identical in painful and painless sentences, and only the reaction when sitting was different when the action was painful (abrupt movement to rise)). As the action type (sitting vs walking) did not interact with other factors, it is less probable that this effect can importantly account for our findings. However, future experiments could explore this point.

One more plausible explanation could be related to an absence or a decrease in the activation of action representation when action words are included in a painful context. Previous research has found that body pain can affect individuals' capacity to use their motor system (Mercier, 2012). Specifically, mental rotation tasks on motor representations have been found to be less efficient among participants suffering from pain than among healthy controls (Coslett et al., 2010a, 2010b). Moreover, some findings have revealed that the motor activation that is linked to action-word processing is related to the degree of effort required to execute an action (Moody \& Gennari, 2010). When an action word is included in a semantic context that requires more effort (e.g., pushing a piano vs pushing a chair), there is more activation in the premotor cortex during this action word's processing. This finding suggests that motor representation activations may vary based on semantic context and, more 
specifically, based on the described action's characteristics. Therefore, in the present experiment, it may be that action representation is less efficient for sentences that evoke pain than those that do not evoke pain. To corroborate this assumption, we asked a group of 59 students to use a 5-point Likert scale to judge whether they could imagine themselves or someone else producing the actions that were described in the sentences that we used in the present study. In line with our hypothesis, they reported that the painful sentences were more difficult to imagine than the painless sentences (mean painless sentences $=4.53$; mean painful sentences $=2.41 ; \mathrm{t}_{58}=9.74 ; \mathrm{p}<0.001 ;$ see Appendix 2 for detailed results $)$.

Finally, it could also be hypothesized that the decrease in action representation activation in the painful context may be related to the participant's motor experiences. Several experiments have shown that motor experience influences the degree of motor activation during action observations (Bidet-Ildei et al., 2010; Calvo-Merino, Glaser, Grezes, Passingham, \& Haggard, 2005) or sentence understanding (Lyons et al., 2010). For example, Lyons et al. (2010) found greater activation in the left premotor cortex among experienced ice hockey players who analyzed sentences that presented specific hockey actions than among non-experienced ice hockey players. In our experiment, words used as complements were controlled for by linguistic parameters (i.e., frequency, number of syllables, and number of letters) but not in terms of motor experience. However, it seems reasonable to think that participants have more experience with painless actions (e.g., walk on the grass, sit on a chair) that painful actions (e.g., walk on thistles, sit on a nail) in their life. This difference in motor experience may explain why action verbs included in a painful context activate action representation less.

To conclude, the present study showed for the first time that pain associated with sentence listening can modulate the link between action-verb comprehension and point-light human movement perception. Consequently, action-verb processing affords sensorimotor 
representation only if the reader understands a suitable and comfortable situation. For us, this effect could be explained by a decrease in motor simulation in painful conditions, related to the fact that humans could be less invested in the simulation. This assumption is theoretically in accordance with the strong embodiment hypothesis of action verbs (Meteyard, 2012) and suggests not that action-verb processing is embodied or unembodied depending on the context (Jamrozik, McQuire, Cardillo, \& Chatterjee, 2016; Leshinskaya \& Caramazza, 2016) but that the strength of embodiment can be affected by the degree of motor simulation (see also BidetIldei et al., In press). However, to our knowledge, this idea has never been investigated, and this will be one of our objectives in the future.

\section{References}

Andres, M., Finocchiaro, C., Buiatti, M., \& Piazza, M. (2015). Contribution of motor representations to action verb processing. Cognition, 134, 174-184. doi: 10.1016/j.cognition.2014.10.004

Anelli, F., Borghi, A. M., \& Nicoletti, R. (2012). Grasping the pain: motor resonance with dangerous affordances. Consciousness and Cognition, 21(4), 1627-1639. doi: 10.1016/j.concog.2012.09.001

Aravena, P., Courson, M., Frak, V., Cheylus, A., Paulignan, Y., Deprez, V., \& Nazir, T. A. (2014). Action relevance in linguistic context drives word-induced motor activity. Frontiers in Human Neuroscience, 8, 163. doi: 10.3389/fnhum.2014.00163

Aravena, P., Delevoye-Turrell, Y., Deprez, V., Cheylus, A., Paulignan, Y., Frak, V., \& Nazir, T. (2012). Grip force reveals the context sensitivity of language-induced motor activity during "action words" processing: evidence from sentential negation. PlOS ONE, 7(12), e50287. doi: 10.1371/journal.pone.0050287

Atkinson, A. P., Dittrich, W. H., Gemmell, A. J., \& Young, A. W. (2004). Emotion perception from dynamic and static body expressions in point-light and full-light displays. Perception, 33(6), 717-746.

Avenanti, A., Bueti, D., Galati, G., \& Aglioti, S. M. (2005). Transcranial magnetic stimulation highlights the sensorimotor side of empathy for pain. [Research Support, Non-U.S. Gov't]. Nature Neuroscience, 8(7), 955-960. doi: 10.1038/nn1481

Avenanti, A., Minio-Paluello, I., Bufalari, I., \& Aglioti, S. M. (2006). Stimulus-driven modulation of motor-evoked potentials during observation of others' pain. [Research Support, Non-U.S. Gov't]. Neuroimage, 32(1), 316-324. doi: 10.1016/j.neuroimage.2006.03.010

Barsalou, L. W. (1999). Perceptual symbol systems. Behavioral Brain Sciences, 22(4), 577-609; discussion 610-560.

Beardsworth, T., \& Buckner, T. (1981). The ability to recognize oneself from a video recording of one's movements without seeing one's body. Bulletin of the Psychonomic Society, 18(1), 1922.

Bicknell, K., Elman, J. L., Hare, M., McRae, K., \& Kutas, M. (2010). Effects of event knowledge in processing verbal arguments. J Mem Lang, 63(4), 489-505. doi: 10.1016/j.jml.2010.08.004 
Bidet-Ildei, C., Chauvin, A., \& Coello, Y. (2010). Observing or producing a motor action improves later perception of biological motion: Evidence for a gender effect. Acta Psychologica (Amst), 134(2), 215-224. doi: 10.1016/j.actpsy.2010.02.002

Bidet-Ildei, C., Gimenes, M., Toussaint, L., Almecija, Y., \& Badets, A. (In press). Sentence plausibility influences the link between action words and the perception of biological human movements. Psychological Research.

Bidet-Ildei, C., Sparrow, L., \& Coello, Y. (2011). Reading action word affects the visual perception of biological motion. Acta Psychologica (Amst), 137(3), 330-334. doi: 10.1016/j.actpsy.2011.04.001

Bidet-Ildei, C., \& Toussaint, L. (2015). Are judgments for action verbs and point-light human actions equivalent? Cognitive Processing, 16(1), 57-67. doi: 10.1007/s10339-014-0634-0

Calvo-Merino, B., Glaser, D. E., Grezes, J., Passingham, R. E., \& Haggard, P. (2005). Action observation and acquired motor skills: an FMRI study with expert dancers. Cerebral Cortex, 15(8), 12431249.

Chouchourelou, A., Matsuka, T., Harber, K., \& Shiffrar, M. (2006). The visual analysis of emotional actions. Social Neuroscience, 1, 63-74.

Coslett, H. B., Medina, J., Kliot, D., \& Burkey, A. (2010a). Mental motor imagery and chronic pain: the foot laterality task. Journal of the International Neuropsychological Society, 16(4), 603-612. doi: 10.1017/S1355617710000299

Coslett, H. B., Medina, J., Kliot, D., \& Burkey, A. (2010b). Mental motor imagery indexes pain: the hand laterality task. European Journal of Pain, 14(10), 1007-1013. doi: 10.1016/j.ejpain.2010.04.001

Gilead, M., Liberman, N., \& Maril, A. (2013). The language of future-thought: an fMRI study of embodiment and tense processing. Neuroimage, 65, 267-279. doi: 10.1016/j.neuroimage.2012.09.073

Heard, A. W., Masson, M. E., \& Bub, D. N. (2015). Time course of action representations evoked during sentence comprehension. Acta Psychologica (Amst), 156, 98-103. doi: 10.1016/j.actpsy.2014.01.017

lacoboni, M., Molnar-Szakacs, I., Gallese, V., Buccino, G., Mazziotta, J. C., \& Rizzolatti, G. (2005). Grasping the intentions of others with one's own mirror neuron system. PLoS Biology, 3(3), e79.

Jamrozik, A., McQuire, M., Cardillo, E. R., \& Chatterjee, A. (2016). Metaphor: Bridging embodiment to abstraction. Psychon Bull Rev, 23(4), 1080-1089. doi: 10.3758/s13423-015-0861-0

Johansson, G. (1973). Visual perception of biological motion and a model for its analysis. Perception \& Psychophysics, 14, 201-211.

Khader, P. H., Jost, K., Mertens, M., Bien, S., \& Rosler, F. (2010). Neural correlates of generating visual nouns and motor verbs in a minimal phrase context. Brain Research, 1318, 122-132.

Kozlowski, L., \& Cutting, J. E. (1977). Recognizing the sex of a walker from dynamic point-light displays. Perception \& Psychophysics, 21, 575-580.

Lamm, C., Decety, J., \& Singer, T. (2011). Meta-analytic evidence for common and distinct neural networks associated with directly experienced pain and empathy for pain. Neuroimage, 54(3), 2492-2502. doi: 10.1016/j.neuroimage.2010.10.014

Leshinskaya, A., \& Caramazza, A. (2016). For a cognitive neuroscience of concepts: Moving beyond the grounding issue. Psychon Bull Rev, 23(4), 991-1001. doi: 10.3758/s13423-015-0870-z

Loula, F., Prasad, S., Harber, K., \& Shiffrar, M. (2005). Recognizing people from their movement. Journal of Experimental Psychology Human Perception and Performance, 31(1), 210-220.

Lyons, I. M., Mattarella-Micke, A., Cieslak, M., Nusbaum, H. C., Small, S. L., \& Beilock, S. L. (2010). The role of personal experience in the neural processing of action-related language. Brain and Language, 112(3), 214-222. doi: 10.1016/j.bandl.2009.05.006

Macmillan, N. A., \& Creelman, C. D. (2005). Detection Theory: A User's Guide (2nd edition). Mahwah, NJ: Lawrence Erlbaum Associates. 
Martel, L., Bidet-Ildei, C., \& Coello, Y. (2011). Anticipating the terminal position of an observed action: Effect of kinematic, structural, and identity information. Visual Cognition, 19(6), 785-798.

Mercier, C. (2012). Interactions between motor imagery and pain. Comment on Raffin et al. (2012). [Comment]. Cortex, 48(6), 778-780. doi: 10.1016/j.cortex.2011.04.013

Meteyard, L. (2012). Trial shows only that practice varies. [Comment

Letter]. BMJ, 345, e6022; author reply e6023. doi: 10.1136/bmj.e6022

Moody, C. L., \& Gennari, S. P. (2010). Effects of implied physical effort in sensory-motor and prefrontal cortex during language comprehension. Neuroimage, 49(1), 782-793. doi: 10.1016/j.neuroimage.2009.07.065

Morrison, I., Poliakoff, E., Gordon, L., \& Downing, P. (2007). Response-specific effects of pain observation on motor behavior. Cognition, 104(2), 407-416. doi: 10.1016/j.cognition.2006.07.006

Morrison, I., Tipper, S. P., Fenton-Adams, W. L., \& Bach, P. (2013). "Feeling" others' painful actions: the sensorimotor integration of pain and action information. [Research Support, Non-U.S. Gov't]. Hum Brain Mapp, 34(8), 1982-1998. doi: 10.1002/hbm.22040

New, B., Pallier, C., Ferrand, L., \& Matos, R. (2001). Une base de données lexicales du français contemporain sur internet: LEXIQUE. L'Année psychologique, 101, 447-462. http://www.lexique.org.

Prieto Velasco, J. A., \& Tercedor Sanchez, M. (2014). The embodied nature of medical concepts: image schemas and language for PAIN. [Research Support, Non-U.S. Gov't]. Cogn Process, 15(3), 283-296. doi: 10.1007/s10339-013-0594-9

Springer, A., Huttenlocher, A., \& Prinz, W. (2012). Language-induced modulation during the prediction of others' actions. Psychological Research. doi: 10.1007/s00426-012-0411-6

Springer, A., \& Prinz, W. (2010). Action semantics modulate action prediction. Quarterly Journal of Experimental Psychology (Colchester), 1-18.

Taylor, L. J., \& Zwaan, R. A. (2008). Motor resonance and linguistic focus. Quarterly Journal of Experimental Psychology, 61(6), 896-904.

Tettamanti, M., Buccino, G., Saccuman, M. C., Gallese, V., Danna, M., Scifo, P., . . Perani, D. (2005). Listening to action-related sentences activates fronto-parietal motor circuits. Journal of Cognitive Neuroscience, 17(2), 273-281.

Toussaint, L., \& Meugnot, A. (2013). Short-term limb immobilization affects cognitive motor processes. Journal of Experimental Psychology: Learning Memory \& Cognition, 39(2), 623632. doi: $10.1037 / \mathrm{a} 0028942$

Troje, N. F., Sadr, J., Geyer, H., \& Nakayama, K. (2006). Adaptation aftereffects in the perception of gender from biological motion. Journal of Vision, 6(8), 850-857.

Troyer, M., Curley, L. B., Miller, L. E., Saygin, A. P., \& Bergen, B. K. (2014). Action verbs are processed differently in metaphorical and literal sentences depending on the semantic match of visual primes. Frontiers in Human Neuroscience, 8, 982. doi: 10.3389/fnhum.2014.00982

van Dam, W. O., Brazil, I. A., Bekkering, H., \& Rueschemeyer, S. A. (2014). Flexibility in embodied language processing: context effects in lexical access. Topics in Cognitive Science, 6(3), 407424. doi: $10.1111 /$ tops.12100

van Dam, W. O., van Dijk, M., Bekkering, H., \& Rueschemeyer, S. A. (2012). Flexibility in embodied lexical-semantic representations. [Research Support, Non-U.S. Gov't]. Human Brain Mapping, 33(10), 2322-2333. doi: 10.1002/hbm.21365

Wilson, M. (2002). Six views of embodied cognition. Psychonomic Bulletin \& Review, 9(4), 625-636.

Zwaan, R. A., Taylor, L. J., \& de Boer, M. (2010). Motor resonance as a function of narrative time: further tests of the linguistic focus hypothesis. Brain and Language, 112(3), 143-149. doi: 10.1016/j.bandl.2008.11.004 


\section{Acknowledgments}

Thank you to Yves Almecija for his participation in building the stimuli.

\section{Appendices}

Appendix 1: Characteristics words used as complements (English translation)

\begin{tabular}{|c|c|c|c|c|}
\hline Words & Condition & Frequency & Number of letters & Number of syllables \\
\hline $\begin{array}{l}\text { Allée } \\
\text { (path) }\end{array}$ & $\begin{array}{l}\text { Painless } \\
\text { Context }\end{array}$ & 9.89 & 5 & 2 \\
\hline $\begin{array}{c}\text { Banc } \\
\text { (bench) }\end{array}$ & $\begin{array}{l}\text { Painless } \\
\text { Context }\end{array}$ & 8.96 & 4 & 1 \\
\hline $\begin{array}{c}\text { Banquette } \\
\text { (seat) }\end{array}$ & $\begin{array}{l}\text { Painless } \\
\text { Context }\end{array}$ & 2.66 & 9 & 2 \\
\hline $\begin{array}{c}\text { Barque } \\
\text { (boat) }\end{array}$ & $\begin{array}{l}\text { Painless } \\
\text { Context }\end{array}$ & 9.52 & 6 & 1 \\
\hline $\begin{array}{l}\text { Canapé } \\
\text { (sofa) }\end{array}$ & $\begin{array}{l}\text { Painless } \\
\text { Context }\end{array}$ & 17.66 & 6 & 3 \\
\hline $\begin{array}{l}\text { Chaise } \\
\text { (chair) }\end{array}$ & $\begin{array}{l}\text { Painless } \\
\text { Context }\end{array}$ & 32.7 & 6 & 1 \\
\hline $\begin{array}{l}\text { Coussin } \\
\text { (cushion) }\end{array}$ & $\begin{array}{l}\text { Painless } \\
\text { Context }\end{array}$ & 2.44 & 7 & 2 \\
\hline $\begin{array}{l}\text { Feuilles } \\
\text { (leaf) }\end{array}$ & $\begin{array}{l}\text { Painless } \\
\text { Context }\end{array}$ & 16.86 & 8 & 1 \\
\hline $\begin{array}{l}\text { Forêt } \\
\text { (forest) }\end{array}$ & $\begin{array}{l}\text { Painless } \\
\text { Context }\end{array}$ & 29.57 & 5 & 2 \\
\hline $\begin{array}{c}\text { Gymnase } \\
\text { (gym) }\end{array}$ & $\begin{array}{l}\text { Painless } \\
\text { Context }\end{array}$ & 4.11 & 7 & 2 \\
\hline $\begin{array}{l}\text { Herbe } \\
\text { (grass) }\end{array}$ & $\begin{array}{l}\text { Painless } \\
\text { Context }\end{array}$ & 27.64 & 5 & 1 \\
\hline $\begin{array}{l}\text { Rocher } \\
\text { (rock) }\end{array}$ & $\begin{array}{l}\text { Painless } \\
\text { Context }\end{array}$ & 10.37 & 6 & 2 \\
\hline $\begin{array}{c}\text { Square } \\
\text { (park) }\end{array}$ & $\begin{array}{l}\text { Painless } \\
\text { Context }\end{array}$ & 5.51 & 6 & 1 \\
\hline $\begin{array}{c}\text { Stade } \\
\text { (stadium) }\end{array}$ & $\begin{array}{l}\text { Painless } \\
\text { Context }\end{array}$ & 14.34 & 5 & 1 \\
\hline $\begin{array}{l}\text { Studio } \\
\text { (studio) }\end{array}$ & $\begin{array}{l}\text { Painless } \\
\text { Context }\end{array}$ & 20.95 & 6 & 2 \\
\hline $\begin{array}{c}\text { Tabouret } \\
\text { (stool) }\end{array}$ & $\begin{array}{l}\text { Painless } \\
\text { Context }\end{array}$ & 2.79 & 8 & 3 \\
\hline $\begin{array}{l}\text { Tapis } \\
\text { (carpet) }\end{array}$ & $\begin{array}{l}\text { Painless } \\
\text { Context }\end{array}$ & 20.13 & 5 & 2 \\
\hline $\begin{array}{c}\text { Terrasse } \\
\text { (patio) }\end{array}$ & $\begin{array}{l}\text { Painless } \\
\text { Context }\end{array}$ & 9.66 & 8 & 2 \\
\hline $\begin{array}{l}\text { Tronc } \\
\text { (trunk) }\end{array}$ & $\begin{array}{l}\text { Painless } \\
\text { Context }\end{array}$ & 4.84 & 5 & 1 \\
\hline $\begin{array}{c}\text { Trottoir } \\
\text { (sidewalk) }\end{array}$ & $\begin{array}{l}\text { Painless } \\
\text { Context }\end{array}$ & 9.93 & 8 & 2 \\
\hline $\begin{array}{l}\text { Aiguille } \\
\text { (needle) }\end{array}$ & $\begin{array}{l}\text { Painful } \\
\text { Context }\end{array}$ & 10.4 & 8 & 2 \\
\hline $\begin{array}{l}\text { Barbelés } \\
\text { (barbed) }\end{array}$ & $\begin{array}{l}\text { Painful } \\
\text { Context }\end{array}$ & 3.25 & 8 & 3 \\
\hline $\begin{array}{l}\text { Bombe } \\
\text { (bomb) }\end{array}$ & $\begin{array}{l}\text { Painful } \\
\text { Context }\end{array}$ & 48.7 & 5 & 1 \\
\hline $\begin{array}{l}\text { Braises } \\
\text { (embers) }\end{array}$ & $\begin{array}{l}\text { Painful } \\
\text { Context }\end{array}$ & 0.93 & 7 & 1 \\
\hline Cactus & Painful & 2.86 & 6 & 2 \\
\hline
\end{tabular}




\begin{tabular}{|c|c|c|c|c|}
\hline (cactus) & Context & & & \\
\hline $\begin{array}{l}\text { Chardons } \\
\text { (thistles) }\end{array}$ & $\begin{array}{l}\text { Painful } \\
\text { Context }\end{array}$ & 0.08 & 8 & 2 \\
\hline $\begin{array}{l}\text { Clou } \\
\text { (nail) }\end{array}$ & $\begin{array}{l}\text { Painful } \\
\text { Context }\end{array}$ & 7.79 & 4 & 1 \\
\hline $\begin{array}{l}\text { Cutter } \\
\text { (cutter) }\end{array}$ & $\begin{array}{l}\text { Painful } \\
\text { Context }\end{array}$ & 2.36 & 6 & 2 \\
\hline $\begin{array}{l}\text { Epines } \\
\text { (thorns) }\end{array}$ & $\begin{array}{l}\text { Painful } \\
\text { Context }\end{array}$ & 3.29 & 6 & 2 \\
\hline $\begin{array}{l}\text { Hérisson } \\
\text { (hedgehog) }\end{array}$ & $\begin{array}{l}\text { Painful } \\
\text { Context }\end{array}$ & 0.69 & 8 & 3 \\
\hline $\begin{array}{l}\text { Méduse } \\
\text { (jellyfish) }\end{array}$ & $\begin{array}{l}\text { Painful } \\
\text { Context }\end{array}$ & 0.66 & 6 & 2 \\
\hline $\begin{array}{l}\text { Mine } \\
\text { (mine) }\end{array}$ & $\begin{array}{l}\text { Painful } \\
\text { Context }\end{array}$ & 36.84 & 4 & 1 \\
\hline $\begin{array}{c}\text { Orties } \\
\text { (nettles) }\end{array}$ & $\begin{array}{l}\text { Painful } \\
\text { Context }\end{array}$ & 1.63 & 6 & 2 \\
\hline $\begin{array}{l}\text { Oursins } \\
\text { (urchins) }\end{array}$ & $\begin{array}{l}\text { Painful } \\
\text { Context }\end{array}$ & 0.34 & 7 & 2 \\
\hline $\begin{array}{c}\text { Punaise } \\
\text { (bug) }\end{array}$ & $\begin{array}{l}\text { Painful } \\
\text { Context }\end{array}$ & 1.41 & 7 & 2 \\
\hline $\begin{array}{l}\text { Rasoir } \\
\text { (razor) }\end{array}$ & $\begin{array}{l}\text { Painful } \\
\text { Context }\end{array}$ & 8.18 & 6 & 2 \\
\hline $\begin{array}{c}\text { Ronces } \\
\text { (brambles) }\end{array}$ & $\begin{array}{l}\text { Painful } \\
\text { Context }\end{array}$ & 0.95 & 6 & 1 \\
\hline $\begin{array}{l}\text { Scorpion } \\
\text { (scorpion) }\end{array}$ & $\begin{array}{c}\text { Painful } \\
\text { Context }\end{array}$ & 1.78 & 8 & 2 \\
\hline $\begin{array}{l}\text { Seringue } \\
\text { (syringe) }\end{array}$ & $\begin{array}{l}\text { Painful } \\
\text { Context }\end{array}$ & 4.39 & 8 & 2 \\
\hline $\begin{array}{l}\text { Vipère } \\
\text { (viper) }\end{array}$ & $\begin{array}{l}\text { Painful } \\
\text { Context }\end{array}$ & 3.42 & 6 & 2 \\
\hline
\end{tabular}

Appendix 2: List of painless and painful sentences. Action representation scores were calculated from results that were obtained from an independent group of 59 participants.

\begin{tabular}{|c|c|c|c|}
\hline $\begin{array}{l}\text { Painless sentences in French } \\
\text { (in English) }\end{array}$ & $\begin{array}{l}\text { Mean score of } \\
\text { action } \\
\text { representation }\end{array}$ & $\begin{array}{l}\text { Painful sentences in French } \\
\text { (in English) }\end{array}$ & $\begin{array}{l}\text { Mean score of } \\
\text { action } \\
\text { representation }\end{array}$ \\
\hline $\begin{array}{l}\text { I'animateur marche sur de l'herbe } \\
\text { (the animator is walking on the grass) } \\
\text { L'athlète marche dans un stade } \\
\text { (The athlete is walking in a stadium) } \\
\text { Le gendarme marche sur un trottoir } \\
\text { (the policeman is walking on a sidewalk) } \\
\text { Le chasseur marche dans une forêt } \\
\text { (the hunter is walking in the forest) } \\
\text { Le voisin marche sur une terrasse } \\
\text { (the neighbor is walking on a patio) } \\
\text { Le comédien marche dans un studio } \\
\text { (the comedian is walking in a studio) } \\
\text { Le gamin marche sur un tapis } \\
\text { (the kid is walking on a carpet) } \\
\text { L'inspecteur marche dans un square } \\
\text { (the detective is walking in a park) } \\
\text { Le vendeur marche dans une allée } \\
\text { (the seller is walking on a path) }\end{array}$ & $\begin{array}{l}4.56 \\
4.76 \\
4.89 \\
4.97 \\
4.76 \\
4.48 \\
4.86 \\
3.94 \\
4.54 \\
3.49\end{array}$ & $\begin{array}{l}\text { I'animateur marche sur des chardons } \\
\text { (the animator is walking on the thistles) } \\
\text { L'athlète marche dans des ronces } \\
\text { (the athlete is walking in brambles) } \\
\text { Le gendarme marche sur une bombe } \\
\text { (the policeman is walking on a bomb) } \\
\text { Le chasseur marche sur un hérisson } \\
\text { (the hunter is walking on a hedgehog) } \\
\text { Le voisin marche sur une vipère } \\
\text { (the neighbor is walking on a viper) } \\
\text { Le comédien marche sur un rasoir } \\
\text { (the comedian is walking on a razor) } \\
\text { Le gamin marche sur des épines } \\
\text { (the kid is walking on thorns) } \\
\text { L'inspecteur marche sur un cutter } \\
\text { (the detective is walking on a cutter) } \\
\text { Le vendeur marche sur une aiguille } \\
\text { (the seller is walking on a needle) }\end{array}$ & $\begin{array}{l}3.76 \\
2.86 \\
2.58 \\
3.66 \\
2.51 \\
2.97 \\
4.41\end{array}$ \\
\hline
\end{tabular}




\begin{tabular}{|c|c|c|c|}
\hline $\begin{array}{l}\text { Le soldat marche dans un gymnase } \\
\text { (the soldier is walking in a gym) } \\
\text { Le garçon s'assoit sur une chaise } \\
\text { (the boy is sitting on a chair) } \\
\text { L'homme s'assoit sur un canapé } \\
\text { (the man is sitting on a sofa) } \\
\text { Le policier s'assoit sur un banc } \\
\text { (the policeman is sitting on a bench) } \\
\text { Le vacancier s'assoit sur un coussin } \\
\text { (the tripper is sitting on a cushion) } \\
\text { Le professeur s'assoit sur une banquette } \\
\text { (the professor is sitting on a seat) } \\
\text { L'étudiant s'assoit sur des feuilles } \\
\text { (the student is sitting on a leaf) } \\
\text { Le touriste s'assoit sur un rocher } \\
\text { (the tourist is sitting on a rock) } \\
\text { Le marin s'assoit dans une barque } \\
\text { (the seaman is sitting on a boat) } \\
\text { Le cuisinier s'assoit sur un tabouret } \\
\text { (the cook is sitting on a stool) } \\
\text { Le promeneur s'assoit sur un tronc } \\
\text { (the walker is sitting on a truck) }\end{array}$ & $\begin{array}{l}4.41 \\
4.45 \\
4.49 \\
4.75 \\
4.87 \\
4.60 \\
4.29\end{array}$ & $\begin{array}{l}\text { Le soldat marche sur une mine } \\
\text { (the soldier is walking on a mine) } \\
\text { Le garçon s'assoit sur un clou } \\
\text { (the boy is sitting on a nail) } \\
\text { L'homme s'assoit sur des oursins } \\
\text { (the man is sitting on urchins) } \\
\text { Le policier s'assoit sur une seringue } \\
\text { (the policeman is sitting on a syringe) } \\
\text { Le vacancier s'assoit sur un cactus } \\
\text { (the tripper is sitting on a cactus) } \\
\text { Le professeur s'assoit sur une punaise } \\
\text { (the professor is sitting on a bug) } \\
\text { L'étudiant s'assoit sur des orties } \\
\text { (the student is sitting on nettles) } \\
\text { Le touriste s'assoit sur un scorpion } \\
\text { (the tourist is sitting on a scorpion) } \\
\text { Le marin s'assoit sur une méduse } \\
\text { (the seaman is sitting on a jellyfish) } \\
\text { Le cuisinier s'assoit sur des braises } \\
\text { (the cook is sitting on embers) } \\
\text { Le promeneur s'assoit sur des barbelés } \\
\text { (the walker is sitting on barbed wire) }\end{array}$ & $\begin{array}{l}2.45 \\
2.41\end{array}$ \\
\hline
\end{tabular}

Appendix 3: English translation of the questionnaire proposed at the end of the experiment

1- Do you participate in physical activities? For how many hours?

2- Among the sentences, some of them were about a sportsman; right or wrong?

3- Among the sentences, some of them were about a collector; right or wrong?

4- Among the sentences, some of them were painful; right or wrong?

5- Please cite the verbs that are used in the sentences. 